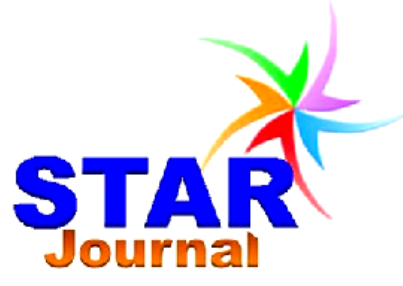

ISSN: 2226-7522(Print) and 2305-3327 (Online) Science, Technology and Arts Research Journal July-Sep 2012, 1(3): 97-105 www.starjournal.org Copyright $\odot 2012$ STAR. All Rights Reserved

\title{
Factors Affecting Students' Performance and Practice on Map Reading Skills: A Case Study of Selected Secondary Schools in Asela Town, Ethiopia
}

\author{
Siddu S. Madiwalar \\ Department of Geography and Environmental Studies, Main Campus Post Box No: 01, \\ Haramaya University, Ethiopia
}

\begin{tabular}{|c|c|}
\hline & Article Information \\
\hline \multirow{3}{*}{$\begin{array}{l}\text { Geographical education empowers the communities to make more meaningful } \\
\text { contributions to the national development by integrating geographical knowledge. Map } \\
\text { reading skills are areas of study in geography, one of the different subjects in the } \\
\text { Ethiopian secondary schools. In Ethiopia, the teaching and learning process of map } \\
\text { reading skills is based on different educational objectives. The teaching and learning } \\
\text { process of map reading skills in secondary schools is aimed at creating skilled manpower } \\
\text { in basic map reading skills based on these objectives. But, nowadays, the teaching and } \\
\text { learning process of map reading skills and the academic performance and achievement of } \\
\text { secondary school students are affected by various factors. This paper is the outcome of } \\
\text { an attempt made to explore the factors affecting the performance and achievement of } \\
\text { students and their level of academic achievement at Chilalo Terara and Alem secondary } \\
\text { schools. A combination of qualitative and quantitative methods was used to investigate } \\
\text { the research problem. For a qualitative part interview questionnaires were used to collect } \\
\text { quantitative data. The percentage is used to show that the level of the performance and } \\
\text { achievement of the students. The findings suggest that possible intervention to help the } \\
\text { students score high academic achievement should focus on teachers' training, enabling } \\
\text { students to work hard persevere to succeed, identifying effective study techniques, the } \\
\text { students' willingness to do school activities and coverage of textbooks' contents. }\end{array}$} & $\begin{array}{ll}\text { Received } & : 23-07-2012 \\
\text { Revised } & : 15-09-2012 \\
\text { Accepted } & : 20-09-2012\end{array}$ \\
\hline & \\
\hline & $\begin{array}{l}\text { Dorresponding Author: } \\
\text { ddu S. Madiwalar } \\
\text { mail: }\end{array}$ \\
\hline
\end{tabular}

\section{INTRODUCTION}

Human development has become an important agenda in the development paradigm in many developing countries like Ethiopia, especially when trickle down model has proved to be inefficient in percolating the benefits of the economic growth to the poor and improving their socio-economic well being. Geographical education empowers the communities to make more meaningful contributions to the national development by integrating geographical knowledge. Maps are very much important in students' daily life for different purposes and at their different life stages whether it is in tourism, for researches, in a planning, on television or as part of a job. The teaching and learning process of map reading skills in secondary schools is aimed at creating skilled manpower in basic map reading skills based on educational objectives.
But, nowadays, the teaching and learning process of map reading skills and the academic performance and achievement of secondary school students are affected by various factors.

This paper deals with the analysis, conclusion and summary of the data obtained through the questionnaires and interviews of senior teachers and a department head of geography, both descriptive and inferential statistics were used for discussion, analysis and concluding the research work. The responses of all the sample teachers and students secured through the questionnaires and interviews of senior teachers and a department head of geography from Chilalo Terara school were used to analyze the factors. Most factors that could have affected the performance and achievement of the whole 
Siddu S. Madiwalar

sample students in map reading skills were analyzed in the sequence

\section{MATERIALS AND METHODS}

Present study is a qualitative type supported by a quantitative approach. Stratified random sampling method was employed as the main tool to collect data. The qualitative method was mainly used to get insight into underlying reasons for the performance and mastery of map reading skills. The primary data was the source of data and was collected through performance test and interviews. The document from the record offices of both sample schools was used for selecting the students who participated in performance test and in responding to interviews.

\section{Study Area}

Asela is located with a latitude and longitude of $7^{\circ} 57^{\circ}$ North and $39^{\circ} 07^{\circ}$ East respectively. It is found at a distance of 175 kilometers along the asphalt road south east of Addis Ababa. It lies west of Mount Chilalo (with an altitude of 4036 m.a.s.I.) on a high plateau overlooking Lake Ziway in the Great Rift Valley of Ethiopia.

According to Oromiya urban planning institute study report on structure plan of Asela town in January 2009, Asela town is founded in 1937 E.C (June 1944 G.C.) as Emperor Menelik II military fort. It has got its name from Oromo people of Asela clans. It is the town found in south central part of Ethiopia in the eastern escarpment of the Great East African Rift Valley in Oromiya national regional state, in Arsi zone, approximately at 2400 meters above sea level. It is surrounded by peasant associations in all directions. Asela is an elongated town (linearly shaped) with total area of $46,231,802 \mathrm{~m}^{2}$ (about $46.2 \mathrm{~km}^{2}$ ). It has an index of compactness of $46 \%$ or 0.46 .

\section{Affecting Factors Analysis}

The analysis of the sample students' performance and achievement test score in map reading skills undoubtedly showed that more than $93 \%$ of the sample students of both sample schools failed to answer half of the items. The research findings showed that only 12 students $(6.82 \%)$ could able to answer more than half of the items, see the last rows of App. Table D. It was also found out that the gap between the highest and lowest test scores for the whole sample students is very high, i.e., $82.50 \%$. There is also very high difference in the test score of performance and achievement in map reading skills between Chilalo Terara (45.03\%) and Alem $(63.75 \%)$ secondary schools. The latter was found to be better than the former both in terms
Sci. Technol. Arts Res. J., July-Sep 2012, 1(3): 97-105

of the proportion of the students who succeeded in answering more than $54 \%$ of the items on average and the mean test score earned by them. The gender gap was also noticed in the mean score of the test both between the sample schools and within each school.

The purpose of this paper is to analyze the possible factors that could have affected the performance and achievement of the whole sample students in map reading skills and resulted in the generally low test score. The responses of all the sample teachers and students of Chilalo Terara and Alem secondary schools secured through the questionnaires were used to analyze the factors. Most factors that could have affected the performance and achievement of the whole sample students in map reading skills were analyzed in the sequence found in the literature review. These are:

\section{Curriculum and School Related Factors}

The curriculum and school related factors include shortage of time allotted for geography teaching and teaching materials and they are analyzed below in detail.

\section{Shortage of Time Allotted For Geography Teaching}

The shortage of time, two periods per week, highly affected the frequency of teaching and learning of geography as well as map reading skills in secondary schools and it was not faire and conducive for both the students and teachers to cover the contents of grades 9 and 10 geography. They considered the shortage of time as complete misfit between the contents to be taught and learnt on one hand and the time allotted for them on the other hand. Both of them thought that the shortage of time had highly affected the teachers' teaching frequency and situation and the students learning opportunity.

It was possible to notice from Table 1 , that 2 teachers $(33.33 \%)$ rated the shortage of time as the $1^{\text {st }}$ factor affecting the teaching and learning process of map reading skills while the other 2 teachers also ranked it as the $2^{\text {nd }}$ factor to affect the process. This indicated that the teachers believed that this factor exerted strong influence on the performance and achievement of the students' in map reading skills. But the sample students rated the shortage of time as the $2^{\text {nd }}$ factor that affected learning of map reading skills next to the lack of teaching aids and materials, see Table 3 . The latter is similar to the previous study by Aklilu (1992). 
Table 1: Major Factors Affecting Map Reading Skills - Teachers' View.

\begin{tabular}{|c|c|c|c|c|c|}
\hline \multirow{2}{*}{ SI. No. } & \multirow{2}{*}{ Affecting Factors } & \multicolumn{4}{|c|}{ No. of Teachers Rated } \\
\hline & & $1^{\text {st }}$ & $2^{\text {nd }}$ & $3^{\text {rd }}$ & $4^{\text {th }}$ \\
\hline 1. & Shortage of Teaching Time & 2 & 2 & - & 2 \\
\hline 2. & Lack of Teaching Aids & - & 3 & 2 & 1 \\
\hline 3. & Students' Interest to Learn & 4 & - & 2 & - \\
\hline 4. & Absence of Cartography Lab & - & 1 & 2 & 3 \\
\hline & Total & 6 & 6 & 6 & 6 \\
\hline
\end{tabular}

\section{Teaching Materials}

Teaching or visual aids are a means of motivation and visualizing teaching and learning but some teachers fail to make adequate use of them, Singh (2005). He continued explaining that visual aids play a significant role in establishing correct, vivid and effective imagery and they are also important as a means of arousing interest and favorable attitude, and securing attention toward learning which are often impossible where learning is wholly upon a verbal basis.

Text books are not adequate without reference materials for teaching and learning map reading skills. This is why it is declared in the Universal Declaration of Human Right 1948, Article 13 (1 and 2) that the development of a system of quality education at all levels shall be actively pursued, and the material conditions of the teaching staff shall be continuously improved. Without the necessary materials the performance and mastery of map reading skills is unexpected.

The teachers and students of the sample schools were asked to identify the available teaching aids from the given list and the following result was obtained (Table 2 ).

Table 2: Availability of Teaching Aids - Teachers and Students View Point.

\begin{tabular}{clcccc}
\hline \multirow{2}{*}{ SI. No. } & \multirow{2}{*}{ Available Teaching Aids } & \multicolumn{2}{c}{ Teachers } & \multicolumn{2}{c}{ Students } \\
\cline { 3 - 6 } & & No. & Percentage & No. & Percentage \\
\hline 1. & World Maps & 6 & 100 & 176 & 100 \\
2. & African Maps & 6 & 100 & 176 & 100 \\
3. & Ethiopian Maps & 6 & 100 & 176 & 100 \\
4. & Other Maps & 5 & 83.33 & 168 & 95.45 \\
5. & Globes & 5 & 83.33 & 168 & 95.45 \\
6. & Pictures & - & - & $*$ & $*$ \\
7. & Graphs & - & - & $*$ & $*$ \\
8. & Diagrams & - & - & $*$ & $*$ \\
9. & Models & - & - & $*$ & $*$ \\
10. & Locally Prepared Maps & - & - & - & - \\
11. & Different Atlases & 5 & 83.33 & 168 & 95.45 \\
\hline
\end{tabular}

* They are not included in the students' questionnaire

Source: Teachers' and Students' Responses through Questionnaire

It is clearly observed from Table 2. that the most available teaching aids were world, African and Ethiopian maps. They are all political maps. The problem was worse when seen in relation to 24 sections and five geography teachers of Chilalo Terara secondary school in which they needed simultaneously these few copies. In addition, as the maps were kept in the school store, they were not available for use in the absence of the storekeeper. In relation to Alem secondary school, as the sections were few in number, only one per grade level and a teacher teaches all the sections and grades, he didn't face this much problem in relation to the number of copies. In addition to these, both schools' teachers informed that there were no cartography laboratory and suitable teaching and learning rooms for practicing and exercising map reading 
Siddu S. Madiwalar

skills. This made the teaching and learning of map reading skills theoretical.

Moreover, 3 teachers (50\%) rated lack of teaching aids as the $2^{\text {nd }}$ factor affecting the teaching and learning of map reading skills next to lack of interest to learn, see Table 10. Most of the sample teachers responded that they were
Sci. Technol. Arts Res. J., July-Sep 2012, 1(3): 97-105

not using teaching aids frequently because of shortage of time and teaching aids and lack of interest to learn with teaching aids on the side of the students. But $95.45 \%$ of the sample students listed the lack of teaching aids as the $1^{\text {st }}$ factor affecting their learning of map reading skills (Table 3).

Table 3: Major Factors Affecting Map Reading Skills - Students' Response.

\begin{tabular}{|c|c|c|c|}
\hline \multirow{2}{*}{ SI. No. } & \multirow{2}{*}{ Major Factors } & \multicolumn{2}{|c|}{ Students' Responses } \\
\hline & & No. & Percentage \\
\hline 1. & Lack of teaching aids and materials & 168 & 95.45 \\
\hline 2. & Shortage of time in learning map reading skills & 160 & 90.91 \\
\hline 3. & Lack of interest and attention to learn map reading skills & 78 & 44.32 \\
\hline 4. & Teachers' lack of ability to teach map reading skills & 75 & 42.61 \\
\hline 5. & Text books do not give enough exercise and explanation & 50 & 28.41 \\
\hline 6. & No response & 58 & 4.55 \\
\hline
\end{tabular}

Source: Students' responses

Table 4: Teachers' Evaluation on the Contents of the Map Reading Skills of Grade 9 and 10.

\begin{tabular}{clcc}
\hline SI. No. & $\begin{array}{c}\text { Nature of Contents Related } \\
\text { Map Reading Skills }\end{array}$ & $\begin{array}{c}\text { No. of } \\
\text { Respondents }\end{array}$ & Percentage \\
\hline 1. & Very vast & 3 & 50.00 \\
2. & Theoretical & 4 & 66.67 \\
3. & Not relevant & 1 & 16.67 \\
4. & Not logically arranged & 1 & 16.67 \\
\hline
\end{tabular}

Source: Teachers' responses

In addition to lack of teaching aids as one factor affecting the teaching and learning process of map reading skills, teachers were asked to evaluate the width of the contents of $9^{\text {th }}$ and $10^{\text {th }}$ grades' map reading skills, see Table 4 . The Table shows that $4(66.67 \%)$ and $3(50.00 \%)$ sample teachers considered the contents as very vast and theoretical respectively. Two (33.34\%) teachers also considered the contents as irrelevant and illogically arranged.

Here, it is rational to attribute the generally low performance and achievement of the sample students in map reading skills to the shortage of teaching aids and materials in addition to the width of contents of map reading skills. That's why researchers explained that students cannot achieve high performance without access to a rich array of learning materials.
We do not achieve what we do not give! Moreover, as visual aids convey an idea more powerfully than written text, their shortage and complete absence is a great defect for the teaching and learning of map reading skills. The geography teachers of sample secondary schools strongly emphasized the shortage of time for the teaching-learning process and teaching materials as the main problems.

\section{Teachers Related Factors}

These factors include teachers' qualification and training on one hand and the courses offered in universities and the interest of the sample teachers on the other hand as the factors affecting the teaching and learning process of map reading skills of the sample teachers and students. 
Siddu S. Madiwalar

\section{Teachers' Qualification and Training}

The teachers' qualification and training as well as their interest to teach the map reading skills could directly affect the sample students' performance and achievement in map reading
Sci. Technol. Arts Res. J., July-Sep 2012, 1(3): 97-105

skills. This is one basic reason why the Ethiopian ministry of education licensed first degree as one requirement for teaching in secondary schools. The sample teachers were first degree holders (Table 5).

Table 5: Teachers' Profile

\begin{tabular}{clcc}
\hline Secondary Schools & Sex & No. of Teachers & Teachers' Qualification* \\
\hline \multirow{2}{*}{ Chilalo Terara } & Male & 5 & First Degree \\
& Female & - & - \\
\hline \multirow{2}{*}{ Alem } & Male & 1 & First Degree \\
& Female & - & - \\
\hline \multicolumn{4}{c}{ Total } \\
* The qualification of teachers includes BA and B.Ed. degree \\
Source: Record offices of sample schools
\end{tabular}

Table 6: Professional Experience of Teachers.

\begin{tabular}{ccc}
\hline \multirow{2}{*}{ Years of Experience } & \multicolumn{2}{c}{ Respondents } \\
\cline { 2 - 3 } & Teachers in No. s & Percentage \\
\hline $11-15$ & 1 & 16.67 \\
$16-20$ & - & - \\
More than 20 & 5 & 83.33 \\
\hline \multicolumn{2}{c}{ Source: Teachers' Responses }
\end{tabular}

So they satisfied that of the ministry of education. They were also well experienced with more than 10 years experience of teaching geography, see Table 6 . These should contribute to achieve higher score but the opposite happened.

\section{The Courses Offered in Universities}

As indicated in the responses of the teachers there were also problems in relation to the map reading courses that were offered in different higher education institutes of Ethiopia, namely Addis Ababa University, Haramaya University and Dila University, where the sample teachers attended their first degree courses. The sample teachers were asked to evaluate the map reading courses that were offered during their first degree education (Table 7).

Table 7: Evaluation of the Map Reading Courses at Higher Education Institutes.

\begin{tabular}{lcc}
\hline \multicolumn{1}{c}{ Teachers' Responses } & No. & Percentage \\
\hline Sufficient but inappropriate for secondary schools & 4 & 66.67 \\
Sufficient and appropriate & 2 & 33.33 \\
\hline
\end{tabular}

Source: Teachers' Responses

Most of the teachers $(66.67 \%)$ said that the courses were sufficient but inappropriate for secondary schools teaching while others $(33.33 \%)$ responded saying that the courses were sufficient and appropriate. This showed that some of them were not satisfied with the courses offered in higher education institutes. This resulted in the lack of the necessary knowledge and skills in map reading which should enable them to teach successfully. In relation to this, all teachers informed that they should get extra references related to time zone, 4 and 6 digit grid references, scale, and contours. 
Siddu S. Madiwalar

\section{The Interest of Teachers to Teach Map Reading Skills}

The sample students were also asked to rate the ability and interest of their teachers to teach
Sci. Technol. Arts Res. J., July-Sep 2012, 1(3): 97-105

map reading skills as high, moderate, low and very low (Table 8).

Table 8: Students' View on their Teachers' Imparting Skills.

\begin{tabular}{ccc}
\hline $\begin{array}{l}\text { Ability and Interest of } \\
\text { Subject Imparting Skills }\end{array}$ & No. & Percentage \\
\hline High & 83 & 47.15 \\
Moderate & 86 & 48.86 \\
Low & 4 & 2.27 \\
Very Low & 3 & 1.72 \\
\hline \multicolumn{3}{c}{ Source: Students' Responses. }
\end{tabular}

The sample students rated the ability and interest of their teachers to teach map reading skills as moderate $(48.86 \%)$ and high $(47.15 \%)$. They also listed this as one factor that affected their learning of map reading skills (Table 1 ). To this end it was important to explain that the dissatisfaction of the sample teachers with the courses offered in higher institutions on the one hand and that of the students with the ability and interest of their teachers to teach map reading skills on the other could also partially resulted in the generally low performance and achievement of the sample students in the test score. The sample students indicated that their teachers covered the map reading skills contents within few periods and treated shallowly.

\section{Students Related Factors}

In the sample schools, some of the problems which caused low performance and achievement of the students in the test score were absence of effective methods of studying and lack of interest to do home works, assignments and other related school activities.

\section{Methods of Studying}

There are various methods of studying different subjects such as SQ3R and others. But the sample students didn't know and use any method of study. They were asked to indicate the method of study they used, see Table 8 . More than $50 \%$ of the sample students responded as they were following their own method. They followed their own methods whether they were effective or not. Even though they had said that they had followed their own methods no one could able to write down the methods they were using. This implies that they didn't know any known scientific method of study. As supported by various researchers, if students knew different methods of study to maximize their score they could able to perform and achieve more than they did. This is true particularly for low achievers.

The teachers of the sample schools reported that they were guiding their students how to study different subjects. But the students could not able to mention any known and scientific method of studying the subject. In addition, the researcher has observed that the Chilalo Terara students lacked study skills such as making notes, summarizing notes, using library and reference books, and working with charts, tables and graphs.

\section{Home Work}

The doing of class works, home works, group works and assignments enable students to practice and apply what they are learning in schools. This also helps them to retain the lesson they learnt for a long period of time and to extend learning beyond class rooms. Researches indicated that home work can produce an effect on learning three times as large as family socioeconomic status. But opposite to this, some students of the sample schools particularly that of Chilalo Terara lacked interest to do class works, home works, group works and assignments. The teachers of the sample schools were asked to rate the curiosity of their students to do class works, home works, group works and assignments (Table 9). The result showed that about $66.67 \%$ of the respondents rated the interest of their students as low and very low.

The students who did class works, home works, group works and assignments were the few students who ranked high in their class ranks. In addition to the lack of curiosity to do school activities, significant number of the sample students, particularly in Chilalo Terara, missed 
Table 9: Students' Studying Methods.

\begin{tabular}{lcc}
\hline \multicolumn{1}{c}{ Study Methods } & No. & Percentage \\
\hline Studying arbitrarily without study method & 18 & 10.23 \\
Simply reading from the beginning to the end & 18 & 10.23 \\
I don't know any method of study & 10 & 05.68 \\
I use my own study method & 89 & 50.57 \\
\hline
\end{tabular}

Source: Students' Responses.

Table 10: Teachers' View about Students' Interest.

\begin{tabular}{ccc}
\hline Students' Interest Level & No. of Teachers rated & Percentage \\
\hline High & 1 & 16.67 \\
Moderate & 1 & 16.67 \\
Low & 3 & 50.00 \\
Very Low & 1 & 16.67 \\
\hline
\end{tabular}

Source: Teachers' responses

many geography classes. Consequently, they had low performance (Table 10) because students who are disengaged from school and learning are more likely to perform poorly, Finn and Rock (1997). In contrast, students who attend school regularly and concentrate on learning are better on standardized tests
(Bandura et al. (1996); Finn \& Rock (1997) and Caraway et al. (2003).

The sample teachers were also asked to rate their students who missed each geography class. Most of the teachers $(83.33 .00 \%)$ indicated that about $1 / 4$ to less than $1 / 4$ of the students missed each geography class (Table 11).

Table 11: Number of students who missed Geography Classes.

\begin{tabular}{lcc}
\hline \multicolumn{1}{c}{ Students' Absentees } & No. of Students Absent & Percentage \\
\hline Half of the students & 1 & 16.67 \\
Two-third of the students & - & - \\
One- fourth of the students & 3 & 50.00 \\
Less than $1 / 4$ of the students & 2 & 33.33 \\
\hline \multicolumn{2}{c}{ Source: Teachers' responses }
\end{tabular}

The researcher observed that a number of students missing each geography class increased from time to time. I supposed that the basic reason not to do different school activities was the missing of the geography classes or school days by large number of students. This was intensified by the fact that map reading contents are in the first units of both $9^{\text {th }}$ and $10^{\text {th }}$ grades. At the beginning of academic year, large number of students missed classes particularly during the Ethiopian September and the beginning of October months.

To sum up, it is likely that lack of interest to do school activities and missing geography classes or school days lowered the performance and achievement of most of the sample students in the test. The researcher also realized that some students were below the understanding ability of their class level.

\section{The effect of Ethiopian general secondary education certificate examination (EGSECE)}

The Ethiopian general secondary education certificate examination (EGSECE) questions on map reading skills contained only few contents of map reading skills. The students of sample schools also concentrated on these few questions instead of learning all the contents of map reading skills. The responses of both 
Siddu S. Madiwalar

students and teachers in relation to general secondary education certificate examination
Sci. Technol. Arts Res. J., July-Sep 2012, 1(3): 97-105

questions were compiled in Table 12.

Table 12: Students' Attention towards map reading skills and other geography contents.

\begin{tabular}{lcc}
\hline Students' Attention towards & No. & Percentage \\
\hline Map reading skills & - & - \\
Other geography contents & 3 & 50.00 \\
$\begin{array}{l}\text { Neither map reading skills nor } \\
\text { other geography contents }\end{array}$ & 3 & 50.00 \\
\hline
\end{tabular}

Source: Students' responses.

Table 13: Teachers response about the Focus on EGSECE questions.

\begin{tabular}{lcc}
\hline \multicolumn{1}{c}{ Focus on EGSECE questions } & No. & Percentage \\
\hline To shape construction in line with the questions & 2 & 33.33 \\
To inform the students where to emphasize while studying & 2 & 33.33 \\
Due to shortage of teaching time & 1 & 16.67 \\
I don't focus on the question at all & 3 & 50.00 \\
\hline
\end{tabular}

Source: Teachers responses

The teachers were asked whether the students gave more emphasis to map reading skills or to other geography contents. As can be seen from Table 13 , half of the teachers $(50.00 \%)$ replied that the students gave more attention to other geography contents rather than map reading contents. The other half said that they gave attention neither to the contents of map reading skills nor to other geography contents. No responses which showed the emphasis of the students towards map reading skills. This showed that the students either didn't give emphasis or they gave less attention to map reading skills.

Moreover, the teachers were also asked whether they focused on EGSECE questions or not when they were teaching map reading skills. Half of the teachers $(50.00 \%)$ answered as they did not focus on the EGSECE questions at all (Table 13). Other teachers (33.33\%) focused on the questions of national examinations of grade 10 to inform the students where to emphasize while studying and to shape their instruction in line with the questions.

Furthermore, the students were asked to rate their teachers' tendency to consult or work out the EGSECE questions on map reading skills.

Most of the students $(60.79 \%)$ rated their teachers' tendency to consult EGSECE questions as high and moderate. In fact, this mismatched with their teachers' responses (Table 13). Only $22.16 \%$ of the students considered their teachers' tendency to consult EGSECE questions as low and very low.

The sample students also evaluated whether their teachers focused on the contents of map reading skills or the other contents of geography. Most of the respondents $(56.82 \%)$ recognized that their teachers' focus was on the other contents of geography instead of map reading contents. This was in agreement with the data in Table 11. Still other students $(31.82 \%)$ rated the focus of their teachers was on map reading skills.

It was realized that the students were in hurry to learn only those contents of map reading appearing in EGSECE questions. When they were learning those contents of map reading which did not appear in EGSECE questions they considered as they were spending their learning time. So this was another convincing reason for low performance and achievement of the sample students in the test.

It is clear from the above analysis that both the sample teachers and students gave more emphasis to the other contents of geography rather than the contents of map reading skills and to only those questions appearing in the EGSECE questions. This is particularly unethical for the teachers. On the behalf of the students, they lost the opportunity to enhance their ability in map reading skills. This was without doubt to be the basic reason for low score of the sample students in the performance or achievement test. 
Siddu S. Madiwalar

\section{CONCLUSION}

After thorough analysis of opinions collected from both teachers and students it is clear that generally students didn't master the seven abilities i.e. knowledge and skill related of map reading which are included in the $9^{\text {th }}$ and $10^{\text {th }}$ grades of secondary schools. Most of the sample students are not aware of the impact of their unwillingness to do school activities, unknowing study techniques/methods and absence of hard work and persevere, and not covering contents of text books on their academic performance and achievement. Such lack of awareness can be improved when schools/teachers, parents and the students work closely together. Schools can create a common front with the students and their parents to increase their students' performance and achievement. All of them can take responsibilities to follow up and guide the students in school activities, study techniques, to help have habit of hard work and persevere, to decrease school absentees and to cover contents of text books. For the common front they can set up a committee or something else and the committee can use ample experiences of senior teachers for the purpose. Parents can play a great role to extend learning and school activities beyond school and school days. Therefore, it is important that parents and schools work closely together to follow up and guide their students to enhance their academic performance and achievement. For this issue to succeed, teachers and concerned government responsibilities should educate students and their parents very well about the issue.

\section{REFERENCES}

Aklilu Dalelo, (1992). Performance of senior secondary students in basic map work skills. Un Published MA Thesis School of Graduate Studies of Addis Ababa University. Pp192.

Assessment Hand book (1995), A Guide for Developing Assessment Programs in Illinois Schools, 1995 edn. Retrieved on 10-06-2010.

Biswas, B. C., (2007). Learn and Teach Geography. Authors Press, Delhi. Pp14 \& 21-22.

Chopra, L. (1967). Parental Occupation and Academic Achievement of High School Students in India. The Journal of Education Research 60(8):359-366.
Sci. Technol. Arts Res. J., July-Sep 2012, 1(3): 97-105

Cohn, E. and Rossmiller, R.A. (1987). Research on Effective Schools. Implication for Less Developed Countries. Comparative Education Review 31(3): 377-387.

Dent, B. D. (1999). Cartography: Thematic Map Design. $5^{\text {th }}$ edn. McGraw-Hill, USA. Pp.14

Dougherty, K. (1981). Research on School EffortsSince the Coleman Report. Harvard Educational Review 51: 301-388.

Ebel, R.L., (1979). Essentials of educational measurement. Prentice-Hall International Inc, London. Pp. 267, 258.

Ferguson, G.A., (1985). Statistical Analysis in Psychology and Education. McGraw-Hill, Auckland. Pp. 428.

Getu Kebede (2010). Analysis of Students' Achievement in Map Reading Skill Test. Un Published M.Ed. Thesis School of Graduate Studies of Haramaya University.

Khan, M.A., (2005). Teaching social studies in secondary schools. Roshan Offset printers, Delhi. Pp.209.

Mathewos Tamiru. (2000). Factors Affecting Academic Achievement of Students at Bole Senior Secondary School. The Ethiopian Journal of Education XX(1).

MOE. (2004). Geography for Ethiopian secondary schools: Curriculum guide for grades nine and ten, Social Sciences Curriculum Development, ICDR. June 2004, Pp.14.

MOE. (2005). Geography grade nine student textbook. Revised edition. Mega Publishing Enterprise, Addis Ababa. Pp. 21-41.

OEA. (2005). University of Washington, Seattle: Improving Learning through Assessment. Retrieved on 10-06-2010.

Rao, M.S. (1990). Dictionary of Geography. Anomol Publication, New Delhi. Pp. 217.

Redding, Sam. (1991). Parents and Learning: International Academy of Education. International Bureau of Education booklet Series 2, PLC, Lausanne, Switzerland. Pp.18-21.

Strahler, Alan H. (1997). Physical geography: science and systems of the human environment. John Wiley and Sons, Inc: USA. Pp. 578.

Walberg, H.J. and Paik, S.J., 1991. Effective educational practices: International Academy of Education; International Bureau of Education booklet Series 3, PLC, Lausanne, Switzerland.

Wareham, A.K. (1969). Map Reading for West African schools. Oxford University Press, London. Pp.iii-1. 